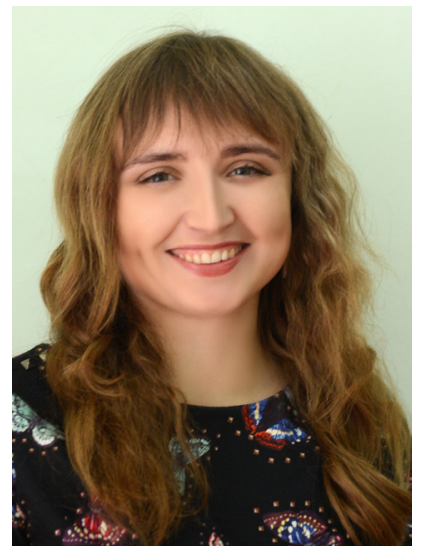

\author{
Ірина Турчин, \\ кандидат педагогічних наук, в. о. доцента \\ кафедри іноземних мов, \\ Львівський національний аграрний університет \\ (м. Дубляни, Україна) \\ Iryna Turchyn, \\ PhD in Education, Acting Associate Professor, \\ Department of Foreign Languages \\ Lviv National Agrarian University \\ (Dubliany, Ukraine) \\ ORCID ID 0000-0003-4630-8273
}

УДК 37.013.44:141.72

\title{
ФЕМІНІСТИЧНА ПЕДАГОГІКА ЯК НАПРЯМ КРИТИЧНОЇ ПЕДАГОГІКИ
}

Анотація. У статті на підставі аналізу поглядів педагогів визначено роль феміністичної педагогіки в сучасній науці. Подано теоретичний огляд феміністичної педагогіки в працях зарубіжних і вітчизняних науковців, що значно розширює ґрунтовне вивчення цієї проблематики. Акцентовано на феміністичній педагогіці як напрямі критичної педагогіки.

Розглянуто проблему феміністичної педагогіки, що $€$ актуальною особливо завдяки вивченню поглядів бразильського педагога і філософа П. Фрейре, який посідає вагоме місце серед когорти відомих педагогів. Визначено роль цієї педагогіки у його працях. Завдяки вивченню праць бразильського педагога з'ясовано, що рівноправне ставлення учня та вчителя, яке П. Фрейре виділяв у «проблемно-орієнтованій» моделі освіти, повинно інтегруватися у феміністичний напрям у педагогіці. Зауважено на важливості студентоцентризму та демократії в освітньому процесі. Досліджено погляди П. Фрейре та А. Шор щодо сексизму під час проведення занять. Проаналізовано праці українських (І. Кизима та Н. Самойленко) і зарубіжних (Дж. Кенвей, Л. Макклюр, Д. Маседо, Г. Модра, П. Фрейре та А. Шор) авторів у контексті вивчення феміністичної педагогіки.

Застосовано такі теоретичні методи, як контент-аналіз, синтез результатів опрацьованих досліджень, а також пошуково-бібліографічний метод.

Розкрито дефініцію «феміністичної педагогіки», що є напрямом критичної педагогіки, в основі якого - стосунки між статями в освітньому процесі, зокрема необхідною умовою якого є зміна ставлення до учениць або студенток. Актуальність статті полягає в ретельному аналізі поглядів П. Фрейре та виділенні аспектів, що є актуальними у феміністичній педагогіці.

Ключові слова: феміністична педагогіка, фемінізм, критична педагогіка, Пауло Фрейре, стать.

\section{FEMINISTRY PEDAGOGY AS A DIRECTION OF CRITICAL PEDAGOGY}

Abstract. One has determined the role of the feminist pedagogy in modern science on the basis of the analysis of educators' views. One has presented a theoretical review of the feminist pedagogy in foreign and Ukrainian scholars' works, which greatly expands the thorough study of this problem. One has emphasized on the feminist pedagogy as the direction of the critical pedagogy.

One has considered the problem of the feminist pedagogy which is relevant, especially due to the Brazilian teacher and philosopher P. Freire's views. One has determined the role of this pedagogy in his works which occupy a significant place in the research of the pedagogy among the cohort of prominent educators. Having studied the Brazilian educator's scientific papers, one has found out the equal relationship between a pupil and a teacher, researched in the problem-posing model of education, should be integrated into the feminist direction in the pedagogy. One has noted the importance of studentcentrism and democracy in the educational process. One has studied P. Freire's and I. Shor's views on sexism during conducting classes.

One has analyzed the works of Ukrainian authors (I. Kyzyma and N. Samoilenko) and foreign authors (J. Kenway, L. McClure, D. Macedo, H. Modra, P. Freire, and I. Shor) in the context of studying the feminist pedagogy.

The research tasks were to study the feminist pedagogy thoroughly and to emphasize on the full potential of the Brazilian teacher P. Freire's views concerning this direction of the critical pedagogy. One has used the following theoretical methods: content-analysis, the synthesis of the results of the researched works as well as search and bibliographic ones.

One has given the definition of "the feminist pedagogy", which is the direction of the critical pedagogy, based on the relationship between the sexes in the educational process, in particular, the necessary condition for the change of the attitude to female pupils or students. The relevance of the article lies in the fact of the elaborate analysis of P. Freire's views and the highlighting the aspects which are relevant in the feminist pedagogy.

Keywords: feminist pedagogy, feminism, critical pedagogy, Paulo Freire, sex. 


\section{ВСТУП}

Постановка проблеми. В умовах розвитку педагогічної науки сучасне суспільство має змогу ознайомитися з кращими зразками досвіду зарубіжжя. Пласт феміністичної педагогіки $€$ одним із пріоритетних напрямів у педагогічних дослідженнях, зважаючи на вагомість поняття фемінізму в модерністських тенденціях сьогодення. Аналіз ситуації в суспільстві засвідчує, що погляди щодо рівності жінок і чоловіків у різних сферах, зокрема економічних, культурних, політичних тощо, займають свою нішу та впливають на розвиток також і в науковому аспекті. Проблема феміністичної педагогіки є актуальною, особливо завдяки вивченню поглядів бразильського педагога П. Фрейре.

Аналіз останніх досліджень і публікацій. Учені активно досліджують феміністичну педагогіку в контексті розвитку світової науки. Зокрема, у працях відомого освітянина П. Фрейре також простежуємо висвітлення цього питання, що розкриває нові аспекти для обґрунтування його актуальності. До проблеми феміністичної педагогіки зверталися такі науковці, як Дж. Гор, Дж. Кенвей, Л. Макклюр, Д. Маседо, Г. Модра та А. Шор. Слід додати, що цінність становлять також наукові роботи українських дослідників, зокрема І. Кизими та Н. Самойленко. Проаналізувавши праці, можемо стверджувати, що феміністичну педагогіку досліджували в різних аспектах, а штрихи, які додав П. Фрейре, свідчать про важливість цієї проблеми.

META I ЗАВДАННЯ ДОсЛІДЖЕННЯ - розкрити сутність феміністичної педагогіки як напряму критичної педагогіки та продемонструвати погляди П. Фрейре на феміністичну педагогіку для глибшого розгляду й осмислення цієї проблематики.

МЕТОДИ ДОсЛІДЖЕНня: для розв'язання завдань дослідження застосовано такі теоретичні методи, як контентаналіз праць українських і зарубіжних науковців та синтез отриманих результатів. Крім того, пошуково-бібліографічний метод є необхідним для обґрунтування ступеня вивчення порушеної проблематики в сучасній педагогічній науці.

\section{РЕЗУЛЬТАТИ ДОСЛІДЖЕННЯ}

Феміністи вважають, що становище жінок у суспільстві недостатньо оцінене, а також не однакове порівняно чоловіками, часто пригноблене. Як зазначають Дж. Кенвей і Г. Модра, для феміністичних освітян «фемінізм є об’єктивом, через який можна інтерпретувати світ, а також впливати на нього» (Kenway J. \& Modra H., 2002, с. 139).

У педагогічній науці $€$ важливий напрям - феміністична педагогіка, яку розглядають із різних поглядів. 3 огляду на визначення терміна в українській думці оперуємо понятями, які розглянуто в працях науковців-педагогів Н. Самойленко (Самойленко Н. І., 2016) та І. Кизими (Кизима І. І., 2016). Хоча І. Кизима у своїй дисертаційній роботі «Гендерні підходи в системі післядипломної педагогічної освіти України (кінець XX - початок XXI століття)» використовує термін «феміністська педагогіка», проте, ґрунтуючись на наукових розвідках, ми вважаємо доцільним уживати термін «феміністична». Цей напрям виник у теорії освіти внаслідок незадоволення патріархатним аспектом у навчанні та «маскуліністськими» дискурсами в освіті (Гор Дж., 2007, с. 98). У той час увага була акценована на навчанні хлопців (чоловіків), що значно погіршувало становище дівчат (жінок), які хотіли здобути знання. Як зауважує Н. Самойленко, у центрі уваги стали стосунки між статями, а не класами. Науковець зазначає, що існував традиційний підхід в освіті, тому прибічники феміністичного напряму вважали, що ставлення в закладах освіти було кращим до чоловіків (хлопців), аніж до жінок (дівчат) (Самойленко Н. І., 2016, с. 460). Дослідження активності учасників освітнього процесу виявили, що учні чоловічої статі активніше вступають у дискусії в процесі вивчення матеріалу, ніж жіночої, жіночі когнітивні стилі теж відрізняються. Зважаючи на такі результати, створення класів, що відповідають жіночій статі, було б доцільним. Окрім того, для феміністичної педагогіки характерний студентоцентризм та демократія в аудиторіях (McClure L., 2000). 3 огляду на це зміна дискурсу в навчанні була винятково важливою не лише з наукового погляду, але й психологічного, адже учасники освітнього процесу повинні також стати людьми з чіткою громадянською позицією, які керуються демократичними принципами. Зважаючи на те, що у світі існує стереотип щодо вибору предметів в освіті, які підходять дівчатам більше, ніж інші, у феміністичній педагогіці визначають два важливих завдання: по-перше, змінити певні аспекти в навчальній програмі, по-друге, викорінити у дівчат їхнє бачення про неправильне (Kenway J. \& Modra H., 2002, p. 144).

Напрямом критичної педагогіки, що відображає погляди П. Фрейре, є феміністична педагогіка. У статті «Феміністична педагогіка та класика» Л. Макклюр зауважує: «У критичній педагогіці стверджується, що знання не є статичними та унітарними, а радше результатом відкритого процесу переговорів та взаємодії між вчителем та учнями. Феміністична педагогіка, як відгалуження критичної педагогіки, також стверджує, що гендер відіграє вирішальну роль у класі, впливаючи не тільки на те, що вчать, але й на те, як його вчать» (McClure L., 2000, р. 53). У критичній педагогіці розглядають негативні наслідки для студентів, спричинені ієрархічними стосунками в школах, а також культурними відмінностями (Kenway J., Modra Н., 1992, р. 143). Принагідно зауважимо, що феміністична педагогіка стала гілкою критичної педагогіки, зосередившись на певних аспектах освітнього процесу.

У феміністичній педагогіці необхідними є демократичність, поєднання емоційних та пізнавальних складових у навчанні, а також розвиток гуманності в освіті (Кизима І. І., 2016). Зокрема, в освітньому процесі важливе партнерство, толерантне ставлення, незважаючи на стать, можливість висловлювати свою позицію. Крім того, визнання несправедливого становища жінок є одним із ключових моментів у трактуванні цінності феміністичної педагогіки. Безперечно, особистісні характеристики та основи нормальних взаємин у суспільстві закладаються в процесі навчання, і цей досвід може допомогти у формуванні світогляду критично мислячої особистості. Погляди П. Фрейре, зокрема про пригноблення та соціальні зміни, є доцільними у цьому напрямі критичної педагогіки. У феміністичній педагогіці також важливо спонукати до критичного мислення та діалогу в навчанні. 
Зауважимо, що П. Фрейре значну увагу приділяв вивченню проблеми пригноблення. Проаналізувавши діалогічне спілкування з Д. Маседо (Freire P. \& Macedo D., 1993), під час якого відповідав на запитання про критику феміністок, він зважав на зауваження щодо «сексистської мови» і просив англійських перекладачів звертати на це увагу в працях, написаних після опублікування «Педагогіки пригноблених». Незважаючи на те, що вчений не виділяв пригноблення жінок у своїй відомій праці, проте ці ідеї близькі до феміністичної педагогіки.

Феміністична педагогіка збагатила погляди на навчання П. Фрейре завдяки «подоланню психологічних, структурних і нормативних перешкод та наданню процесу навчання більшої емоційної насиченості» (Самойленко Н. І., 2016, с. 460). Учні стають активними й усвідомлюють свої права, а освітній процес є емоційнішим та цікавішим.

У світі активно розглядають і засуджують расову упередженість, проте навіть люди, які зазнають пригноблення, можуть також бути гнобителями. Дуже влучно написав П. Фрейре про те, що «навіть пригноблений афроамериканець насолоджується привілейованим становищем стосовно до афроамериканки» (Freire P. \& Macedo D., 1993, p. 170).

А. Шор досліджував прояви сексизму під час проведення занять. Зокрема, студенти часто перебивали студенток, а він, відповідно, перебивав представників чоловічої статі, акцентуючи на рівному праві висловлення думки. Позиція П. Фрейре відрізнялася, бо він вважав, що жінки самі повинні здобути визволення, а викладач не повинен робити це за них. Крім того, чоловіки, які поділяють думку жінок, можуть допомогти їм (Freire P. \& Shor I., 1987).

В освітньому процесі «проблемно-орієнтована» модель освіти, яку розробив П. Фрейре, є необхідною в пропагуванні феміністичного напряму в педагогіці. Зокрема, рівноправне ставлення учня та вчителя повинно бути одним із ключових моментів для вмотивованої діяльності усіх учасників. Не менш важливим є факт соціальних змін у суспільстві. Приєднуємося до ідеї П. Фрейре: якщо вчителі поважають учнів, незважаючи на стать, колір шкіри чи соціальний клас, то зменшують дистанцію між сказаним і зробленим та зміцнюють демократичний клімат у навчанні (Freire P., 2005).

\section{ВИСНОВКИ ТА ПЕРСПЕКТИВИ ПОДАЛЬШИХ ДОСЛІДЖЕНЬ}

Отже, феміністична педагогіка - це напрям критичної педагогіки, в основі якого є стосунки між статями в освітньому процесі, а необхідна умова - зміна ставлення до учениць або студенток. Характерними рисами цієї педагогіки є демократичне середовище в освітньому процесі, толерантність, відкритість до діалогу та критичного мислення. Напрям став популярним завдяки великій кількості досліджень із цієї проблематики. Зауважимо, що ідеї П. Фрейре щодо рівноправного ставлення учня та вчителя співзвучні з феміністичною педагогікою. Перспективою подальших наших досліджень вважаємо ґрунтовне вивчення праць послідовників П. Фрейре в контексті феміністичної педагогіки.

\section{СПИСОК ВИКОРИСТАНИХ ДЖЕРЕЛ}

Гор, Дж. (2007). Феміністська педагогіка та педагогіка по-феміністськи. Філософія освіти. Київ, 1(6), 91-107.

Кизима, І. І. (2016). Гендерні підходи в системі післядипломної педагогічної освіти України (кінець XX - початок XXI століття). (Кандидатська дисертація). Дрогобич.

Самойленко, Н.І.(2016). Передумови виникнення ґендерного підходу у педагогічній науці. Молодий вчений, 6, $458-462$.

Freire, P., \& Shor, І. (1987). A pedagogy for liberation: dialogues on transforming education. Houndmills; Macmillan Education; South Hadley, MA, Bergin \& Garvey.

Freire, P., \& Macedo, D. (1993). A dialogue with Paulo Freire. Paulo Freire: a Critical Encounter (P. Leonard, \& P. McLaren, ed.) Routledge, 169-176.

Freire, P. (2005). Teachers as cultural workers: Letters to those who dare teach (D. Macedo, D. Koike, \& A. Oliveira, Trans.). Boulder, CO: Westview Press.

Kenway, J., \& Modra, H. (1992). Feminist pedagogy and emancipatory possibilities. Feminisms and critical pedagogy (C. Luke, \& J. Gore, ed.), 138-166.

McClure, L. (2000). Paedagogus: Special Section on Feminist Pedagogy: Feminist Pedagogy and the Classics. The Classical World, Vol. 94 , Is. 1, 53-55.

\section{REFERENCES}

Gore, J. (2007). Feministska pedahohika ta pedahohika po-feministsky. Philosophy of Education. Kyiv. 1(6), 91-107.

Kyzyma, I. (2016). Henderni pidhody v systemi pisliadyplomnoii pedahohichnoii osvity Ukraiiny (kinets XX - pochatok XXI stolittia). (Candidate's thesis). Drohobych.

Samoilenko, N. (2016). Peredumovy vynyknennia hendernoho pidkhodu u pedahohichnii nautsi. Young Scientist, 6, 458-462.

Freire, P.,\& Shor, I. (1987). A pedagogy for liberation: dialogues on transforming education. Houndmills; Macmillan Education; South Hadley, MA, Bergin, \& Garvey.

Freire, P. \& Macedo, D. (1993). A dialogue with Paulo Freire. Paulo Freire: a Critical Encounter / ed. P. Leonard, P. McLaren. Routledge, 169-176.

Freire, P. (2005). Teachers as cultural workers: Letters to those who dare teach (D. Macedo, D. Koike, \& A. Oliveira, Trans.). Boulder, CO: Westview Press.

Kenway, J., \& Modra, H. (1992). Feminist pedagogy and emancipatory possibilities. Feminisms and critical pedagogy (C. Luke, \& J. Gore, ed.), 138-166.

McClure, L. (2000). Paedagogus: Special Section on Feminist Pedagogy: Feminist Pedagogy and the Classics. The Classical World, Vol. 94, Is. 1, 53-55.

Статтю подано до редколегії 07.04.2019 p.

Рекомендовано до друку 29.04.2019 p. 